\title{
Adaptive Reuse of Industrial Heritage with Cultural-creative Industry
}

\section{-- A Study of 798 Art District}

\author{
Congcong Yao
}

\author{
Bartlett School of Environment, Energy \& Resources, University College London, London WC13
}

6BT, United Kingdom

\author{
congcong.yao.19@ucl.ac.uk
}

\begin{abstract}
This research aimed to explore the adaptive reuse pattern of the industrial heritage in the 798 Art District. It looks at how the relatively mature Cultural-creative industry links to urban regeneration activities, and what can be learnt from the redevelopment experience. In particular, it explores the role of the Cultural-creative industry and how it used the local industrial heritage to achieve the current layout and operation model of 798 art district. The adaptive reuse model of industrial heritage and the cultural - creative industry is assessed, the current issues and some targeted suggestions of 798 Art District are identified. During the historical evolution, the combination of the deserted urban land and the Cultural-creative industry worked as a successful redevelopment model. Although several studies have summarized of the development history of 798 Art District and its significant role in urban land and art markets, there has been little research on the role of creative class and industrial heritage in art districts and local tourism. This research will first provide literature review looking at the definition and development process of the Cultural-creative industry, the conservation and reuse of industrial heritage and the real-life cases of the reuse of industrial heritage in China. Then, the in-depth quantitative and qualitative methods are used to examine the development trajectory and characteristics of Beijing 798 Art District, the visitors' tourist experience and the role of industrial heritage at the site. Ultimately, the discussion part will provide the comparison between 798 Art Districts with contemporaneous cases of industrial heritage reusing, and provide some recommendations to future development and operation.
\end{abstract}

Keywords: Cultural-creative Industry; Industrial Heritage; Adaptive Reuse; Beijing 798 Art District; Creative Class; Cultural Policies.

\section{Introduction}

For the past three decades, with the acceleration of the globalization trend has led to new scientific and industrial revolutions worldwide, and followed by an industrial shifted from resource-led to innovation-led. Moreover, the relationship between economies, cultures and cities has also been repositioned. The attraction to the creative class and the consequent culture-led regeneration process reflects human creativity as the new 'magic bullet' for economic development [1] [2]. The competition among cities, regions and countries also changed to competition in independent creativity. For an urban perspective, culture soft-power is an inevitable requirement for accelerating the urbanization process, transforming the economic model, and establishing a culturally powerful country [3]. With the Cultural-creative industry became the mainstay industry of national economy since the 21st century, urban cultural districts are also becoming the significant carrier of urban culture and the creative class. In addition, this industry and relevant policies provide the second life to the old town and discarded urban space. Especially, the industrial heritage possesses the existed structure and low-rent, which is popular with artists and creative groups.

As the avant-courier of the Chinese cultural-creative industry due to its relatively mature operation model and plentiful content, Beijing's 798 Art District has integrated industrial heritage with political, economic and cultural elements. As a mature art district with the highest reputation in China, the heritage-based, new industry development model of the 798 Art District is worth exploring and evaluating. 
This paper explores the adaptive reuse of industrial heritage in Chinese cities by focusing on the 798 Art District and looking at how the local cultural-creative industry links to the reuse activities. It also asks what can be learnt from the regeneration experience, and investigates the development issues of current condition of the site and propose recommendations. This paper is divided into five parts, the next section will demonstrate a literature review of Cultural-creative industry, industrial heritage and evolution of industrial heritage reuse. The 'Methodology' part will outline the research methods, and the research results are provided in the following section. The discussion about the findings, recommendations for improving the art district and research limitation will be discussed.

\section{Literature Review}

\subsection{Cultural-creative Industry and the Development}

The rise of the creative industry across the globe has led it to be regarded as a new growth point for economic development similar to the high-tech industry, and it has become an important part of urban development and regeneration. Schumpeter defined the initial concept of 'innovation' as the entrepreneurs proceed a series of 'recombining resource' activities to change new ideas into economic incomes (new products and organizational structures) [4]. The creative industry usually refers to the economic activities which be built on the use and production of knowledge and information. The industry applies innovation and creativity as the core and integrates the technology, culture, and economy, e.g., broadcasting, music industry, sculpture, film industry, print and electronic publishing, advertising and marketing, video and digital game, industrial design and architecture [5] [6]. From its development trajectory, the creative industry is originated from the cultural industry, although the two industries have different definitions, the creative industry is the core element, the highest form and the future development of the cultural industry. The development of the industry was greatly accelerated urban regeneration process, especially that embodied in the reconstructing urban structure and dismissed areas, recombining the budget structure and reconfiguring the stakeholder alliances [4]. At present, the industry has provided considerable economic benefits and the emergence of the cosmopolitan economic tide is derived from the contribution of the creative industry to national economies. Indeed, most developed countries' governments have included the creative industry in their medium- and long-term strategies [5] [7].

Similar to most developed countries, the Chinese administration has emphasised the 'creative country' target as the development core during the 'Eleventh Five-Year Plan'. It is hoped that stronger independent innovation capabilities will change the concept of 'Made in China' to 'Created in China' [5]. For the Chinese development situation of creative industry, the name 'Cultural-creative industry' is more appropriate Chinese market circumstance. Specifically, the industry provides culture and entertainment products and services with higher added value, and the design industry is focus on the craft/art design services, art pattern design services and booth design services [5]. Meanwhile, the production and sale of cultural products and equipment has integrated with tourism and cultural services. As the basis for a new development strategy, most provinces have launched relevant policies to promote the cultural-creative industry. China is expected to become an innovation-oriented society' in 2020 and achieve 'indigenous innovation' to lead the worldwide creative industry by the mid-21st century [8].

\subsection{Conservation and Reuse of Industrial Heritage}

\subsubsection{Definition of Industrial Heritage}

The word 'heritage' is to be interpreted as behavior that inherits valuable items from other people. The literal explains of 'heritage' has stated as the 'past', and the 'use of the past' [9]. The follow-up studies show the concept of heritage has simultaneously emphasized on 'inheritance' and 'conservation', meanwhile, the 'heritage' need to some tangible or intangible carriers to demonstrate their characters ('buildings', 'properties' and 'objects') [10]. In addition, with the connection between 
heritage and culture is gradually strengthening, heritage and conservation activities are increasingly deemed and valued as a social and cultural procedure [11].

The industrial heritage was derived from the development of the urban industry since the Industrial Revolution in the 18th century and the deindustrialisation process after WWII. Based on the research of World Heritage Centre, industrial heritage not only possesses the common character for heritage, but also the industrial heritage is regarded as a particular cultural heritage since this kind of heritage is witnessing the creativity and destruction of humans, visions of a better life, and increasingly powerful material basis [12]. Also, some research mentioned that the initial definition of industrial heritage is 'industrial cultural remains always possess historical, technological, social, architectural or scientific value, and social activities places affiliated with industrial production' [13]. Moreover, the industrial heritage includes the industrial factory and mill which be built after the Industrial Revolution and the achievements in social and engineering perceptive throughout all the phases of human development [12].

\subsubsection{Value of Industrial Heritage}

Based on the definitions of industrial heritage, the subsequent conservation and reuse of this kind of heritage is closely related to the determination of the value of industrial heritage. The value of most heritage is defined by the object, site and the relationship in society determine between the observers and the specific objects [14]. The overall value of the industrial heritage could be divided into 'intrinsic value' (historical, scientific, and aesthetic value) and 'utilitarian value' (economic and educational value) [15]. Moreover, the spiritual value of industrial heritage in national and urban perspective also should be focused. Specifically:

- Historical value (universal value) records the specific historical activities in the industrial structure, civilization, technology, organisation and culture.

- Technological value (specific value) contains the achievements of modern science and the Industrial Revolution, scientific production and organisational methods.

- Aesthetic value of the industrial heritage is always reflected in the structural logic and precise structure in industrial buildings and machines will represent the architectural, machine and urban aesthetics.

- Economic value of the industrial heritage is reflected in the combining of the conservation with economic-social development and industrial restructuring.

- Educational value of the industrial heritage is an extensive social significance, which could provide existing sites in history and engineering education. Also, these sites could organically integrate the industrial heritage conservation, publicity and education.

- Spiritual value of the industrial heritage mainly reflected in its national and urban level. It is the spiritual bond in cities and the common experience of all citizens that help enhance national pride and cohesion.

\subsection{The Reuse of Industrial Heritage with Cultural-creative Industry and Chinese Practices}

From the clause of TICCIH (The International Committee for the Conservation of Industrial Heritage), the conservation of cultural continuity in industrial heritage is more important than its universal value since that could provide opportunities to urban declining areas and their communities [16]. The conservation of industrial heritage originated in the mid-20th century in the UK, and since the 1960s, the countries and districts in the United State and Europe who entered the post-industrial era have been focused on the conservation, transformation and reuse of industrial historical buildings [17]. Following, most urban regeneration activities were conducted around the adaptive reuse and redevelopment of industrial heritage to promote transformation. Also, the industrial heritage has also used as a particular carrier for individuation and socialisation as it can guarantee the further development of urban space and has commemorative, symbolic and educational significance, which is key to the reconstruction of the collective memory of the cities [18].

In China, the conservation and reuse of industrial heritage started in the late 1980s, but most regeneration activities were limited by undeveloped economic and technological issues. Most 
Chinese urban regeneration cases adopted the methods of 'demolition, construction and overthrowing', the 'reuse and redevelopment' of industrial historical buildings only spontaneously apply on small scale [17]. More recently, the importance of industrial heritage had gradually recognised by the government, and it makes possible the mix of industrial heritage and creative class, accompanying the growth of sustainability the urban image has been reshaped [19]. This combination provided internal and external opportunities to promote the rise of Chinese art districts [20]. First, the rebuilding of the relationship between government and artists to establish a new social contract and acquire funds support. Moreover, from the 1980s to the late 1990s, the downsizing of state-owned enterprises provided ready-made vacant properties, while the scarcity of land resources and the transformation of public aesthetics have brought the opportunities to industrial heritage. The above triggers promoted the explosive increase of cultural district during the late 1990s and the early 2000s. The mix of industrial succession, land-use reform and stimulative cultural policy had become common characteristics in some industrial heritage redevelopment cases. Like the development mode of 798 Art District, Shanghai M50 and Guangzhou Xinyi International Club were also developed on the basis of industrial heritage and cultural policies in the 1990s. All three sites evoked the cultural district development process in their respective cities.

\subsubsection{Shanghai M50}

At the same period as 798 Art District, the story of Shanghai M50 Art District is original from the Suzhou creek that was deindustrialised since the 1990s. In 1998, Teng Kun-Yen, a Taiwan architect, rent a discarded warehouse as own design studio. Numerous other cultural workers then followed suit and started renting the dilapidated production facilities and warehouses, those old buildings were carried the original functions with textile industry, the huge space and good lighting is popular with artists [21]. In the same year, the Shanghai Municipal Government conducted the poll and on-site study and evaluation for the heritage in urban areas and listed Excellent Heritage Buildings to conserve and reuse [22]. The subsequent protectionism of the built environment promotes the launch of conservative legislation and the government awareness of industrial heritage. Afterward, the municipal government decided to set the 'Creative Industrial Agglomeration Area' to reuse local industrial heritage by the Cultural-creative industry. The industrial heritage was advertised by policies and media, and that was listed in the municipal proposal to build public space.

However, the M50 has faced the risk of demolition and debate about its existence, the preservation of this art district is thanks to the local urban planners and international media focus. Specifically, the famous urban planner Ruan Yisan became the spokesman of local artists, and Teng Kun-Yen granted an award by UNESCO for his attempt on industrial heritage [21]. With the media widely broadcasting the above events, the municipal government has re-focus on the operation of M50, a series of measures to be complimented as the 'saving of city image by the municipal government in the globalisation', and that let Shanghai Government was nominated as 'First batch of cultural creative industrial clusters' in 2005 [24]. Nowadays, M50 is one of the most popular art districts in the Suzhou Creek, which possesses over than 50 buildings and 24,000 $\mathrm{m}^{2}$ area, more than 150 artists, architect and design firms, contemporary art galleries and [21].

The development process of Shanghai M50 is from the artists spontaneously gathered and local state-owned enterprises followed the related policies to guide the development. Rapid urbanisation process may cause public awareness for heritage showing the retrogressed trend, the original inner structure of the old buildings facing to be demolished to provide development to new functions [22]. In current times, Shangtex is the main investors and that form the public-private partnership to manage this district [24]. Although the district is full of commercial reputation in international, the tourist groups are relatively single, and the place is being criticised for lack of contact with the surrounding neighbourhood. The management issues are caused by the interior industry structure and poor layout [22]. Specifically, 70\% of clients of the place are galleries and artists' studios, which determine most visitors are collectors and art lovers. Also, the shortage of public space in the cultural district makes the current space only for walking, and the low openness has blocked the connection 
with the surrounding community. This has negatively impacted the site's environment and further limited its vitality.

\subsubsection{Guangzhou Xinyi International Club}

The collaboration of the Cultural-creative industry and industrial heritage also occurring in Pearl River Delta at the end of 1990s. The Cultural-creative industry provides the vitality to the old factory and warehouse in the waterfront of Pearl River, and Guangzhou government launched relevant polities for 'suppress the secondary industry and vigorously develop the tertiary industry' to awaken local old towns, old factories and old villages [25]. At the beginning of new millennium, a series of real estate developers became the major investor to the regeneration of this area. The Xinyi International Club was built in an old hydro-power station in Litchi Bay of Pearl River, and invested 40 million RMB by Guangdong Minghuiyuan in 2004 and operated in 2007 [26]. Around 18,000 $\mathrm{m}^{2}$ of industrial land was transformed into commercial land, the designers have used the sleepers, river stones, red bricks, steel and ceramics to decorate the internal structure of old factories, and the current layout of this place includes the open plaza, commercial apartments, green space and catering industry [27]. The Xinyi International Club is the most influential creative park for the appropriate combination among art, commerce and industrial heritage in Guangzhou, which was promoted the development of historic industrial areas of the Pearl River under the government policies [26].

However, local industrial lands have faced the issues caused by tenancy term and lack of local creativity. Although tenancy issues associated with the old factories were addressed in 2010, there is still a lack of real artist groups and a creative class. The creative organisations and companies (i.e., advertising companies, architectural design offices and cultural media companies) that make up the major clients determine the economic income will come from the products' exhibitions, media activities and performances. Also, the inadequate creativity and economic model cause the serious social isolation. The art district is classified as high-end space for the specific cultural elites, rather than a public space for tourist and residents [24].

\section{Methodology}

The adoption of methodology for data collection in this research is mainly relied on quantitative and qualitative method. The quantitative data is collected from the 135 copies answers of the online questionnaire about the tourism experience and industrial heritage of 798 Art District, and the national database finding. Meanwhile, the desk-based study of existed research and the answers (70 copies) of opened-end question in the questionnaire will help the research to know the formation process of the art district and collect the suggestions about current condition. As for the analysis step, thematic analysis will be conducted on the analyzing of answers of questionnaire, the trend analysis and content analysis will be conducted on the collected secondary resources of statistics, policies and documentaries.

\section{Policy and Creative Class Revolution}

\subsection{From 1st Five-year Plan to Reform and Opening-up Policy}

Traced back of the development trajectory of 798 Art District, local industrial heritage is the live eyewitness of this area. Undertaking the modern urban system of North China, the local port towns, traffic towns and mining towns had provided the strong economic base to the political center (Beijing). The surrounding 'port-town' urban layout have directly promoted stations, mine factories and Concession turned into economic cores in Beijing [28]. When the People Republic of China was founded, a series of the large, high-density factory complexes were built to support the heavy and military industry in the suburban area of Beijing. For example, the predecessor of 798 Art District is the '718 Joint Project' that produced electronic military components in Dashanzi area (Fig 1) [29]. The First Five-year Plan (1953-1957) announced that China would 'Concentrating the major forces 
to conduct the industrial construction, which is concerted on 156 construction units designed by the Soviet help to China and consisted of 694 construction units above quota'. In 1953, experienced experts and designers from East Germany had proceeded to Bauhaus style factory with large warehouse and good lighting [30].

The ' 718 Joint Project' had completed and started to produce in 1957, the complex covered around $500,000 \mathrm{~m}^{2}$ and composed of 6 self-contained factories (706, 707, 718, 751, 797 and 798) [31]. The six large-scale industrial complexes had consisted the big flagship project, the layout of the project was demonstrated as a completely self-sufficient industrial city which include theatre, libraries, shops and sport equipment, and the state-owned factory would provide housing, health-care and education service to the worker with their families [29] [32].

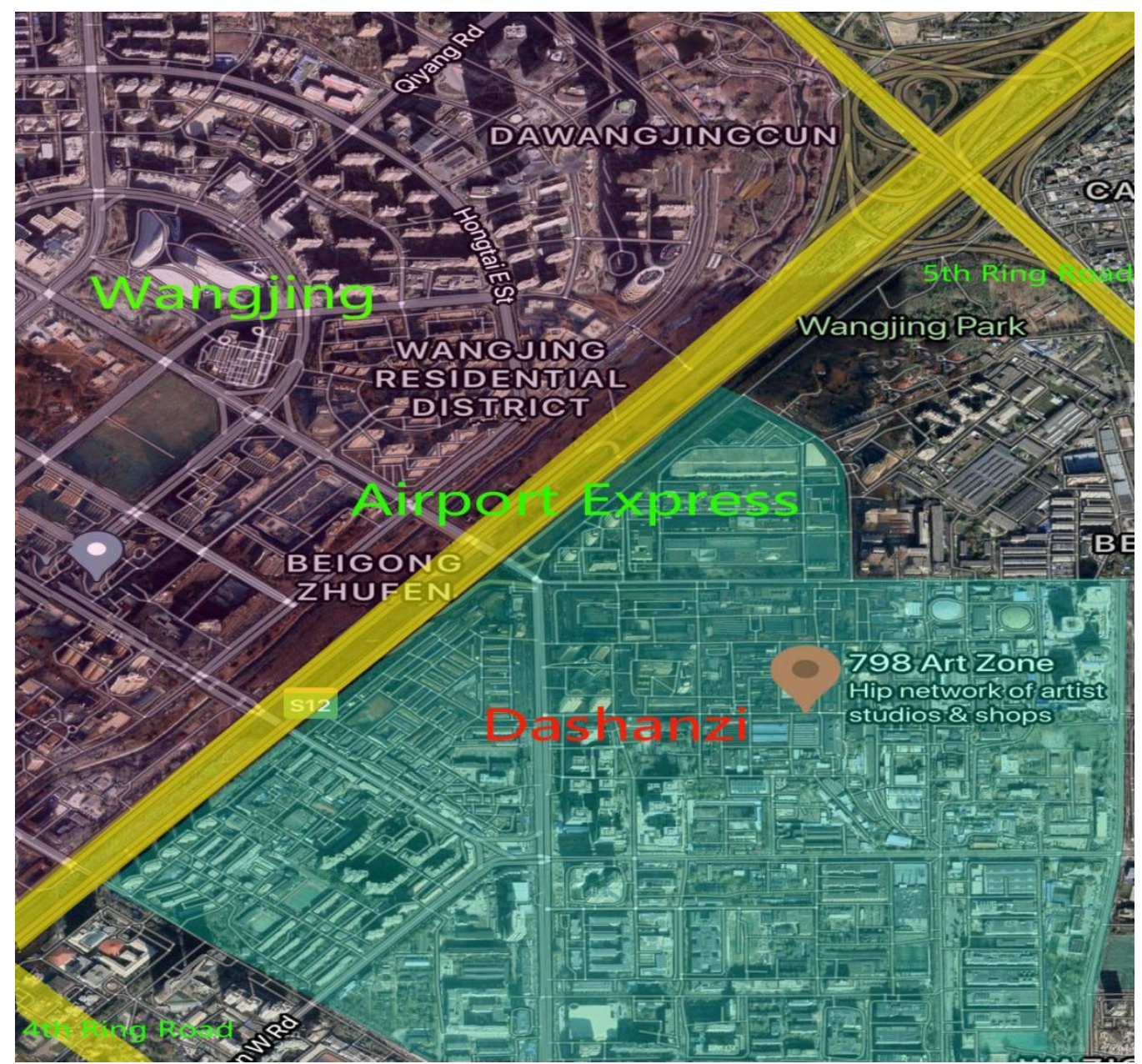

Fig 1. Dashanzi and Wangjing

The collective industry production model lasted until the 1980s, the Reform and Opening-up Policies (1978-2008) promoted the reform of the economic structure and the Chinese urbanisation process [33]. The two influences have provided precondition to the formation of the 798 Art District. The reformation has promoted the privatisation of state-owned companies, which caused stiff competition and eliminated a number of inefficient state-owned enterprises. The Special Economic Zone in the cities has increased the economic freedom as the multinational enterprises and external investment impacted the original industrial system [34]. As the biggest factory on the Joint Factory, the 798 Factory faced high cost, and that had placed on a negative competition position with the same kind of enterprises located on Special Economic Zone. This led to 798 Factory suspending production in the early 1990s, and nearly $60 \%$ of workers had been laid off, and the property management company for the local factories was reconstituted as Seven-Star Huadian Science and Technology 
Volume 13 (2021)

Group and became responsible for finding new tenants. It was not until the first artists arrived that factory 798 was revitalised.

\subsection{Contemporary Art, Artists with Factory 798}

The artists are the key element for the reopen of Factory 798, as the pioneer of the local Culturalcreative industry, the triggers of artists came to this site is need to explore. Based on the existed study of Chinese art history, the art even culture is always intertwined with politics for a long time. For instance, during the Maoist Era (1949- early of the 1970s), art was obedient to the politics, although their identity was recognized by the government, they had to receive official training to join Artist Union, the major artistic work was embodied the socialist realism and Chinese folk art [35]. Under the circumstance, the stagnant art market could not drive the urban economic development. Reform and Opening-up Policies had caused the commercialisation of art and culture, and self-expression and freedom of spirit for artists was injected into their artworks that facilitated the development of Chinese art market [29]. However, the artist group was been seen as underground elitists, the economic benefits of industry cause the artists always at the disadvantage in the competition with commercial land users, and the artists enclaves began to appear on the outskirt of cities [21] [36]. The abandoned factory complex in Dashanzi has provided lots of vacant factories are possess spacious space and good day-lighting, compared with the workplace in the downtown, nearly $0.3 \mathrm{Yuan} / \mathrm{m}^{2} /$ Day rent price has attracted the arrival of first batch artists [29]. Also, the development of 798 Art District is directly related to the relocation of Central Academy of Fine Arts (CAFA) from downtown area to Wangjing (pink area in Fig 1). The first batch of artists of the 798 Art district had included Sui Jianguo (Dean of the Sculpture Department of CAFA), Liu Suola (Chinese musicians and Modernist writers) and some original artists from Yuanmingyuan Art District, in 1995, Sui Jianguo has rent a big warehouse in the original factory complex to design and manufacture the sculptures [3]. Other artists entered to old factories by the students and professors in CAFA successively, the gathering place for artists became the prototype of China's contemporary art district.

\section{Industrial Succession and Subsequent Development}

\subsection{From Bottom-up to Standard Guidance}

Larger working space, cheaper rent and some artists were obliged to move from original art enclaves in the mid-1990s in Beijing (i.e., art village in Summer Palace) became the main triggers of the development of 798 [37]. Since 1995, avant-garde Chinese artists moved to the deserted factories of the Dashanzi area, the 798 began to exist as an 'art community' to provide the living and working space for artists. The establishment of Seven Star Group (in 2000) was key to the operation of this site, when it inherited the property right of 718 Joint Project and that kept a mutually beneficial relationship with artists until 2003. Specifically, artists contain the workplace and residence, Seven Star Group could receive rent revenue for factories to pay compensations and pensions to former employees of the factory complex. In 2003, approximately 30 artists (included two foreign artists) and 40 art firms had registered and operated [36]. In addition, the globalisation process causes the urban competition and fund flow, the domestic and international galleries, exhibitions, oversea art enterprise and Art Festivals occurred in 798 Art District, which boosted the prosperity of art market and enhanced artistic atmosphere [3].

Following development stage was received controversial comments was marked the end of 'honeymoon period' between landlord and artists, there were heated discussion about whether original factories should be demolished is the major theme during this stage. The fuse of the discussion is from the landlord tried to find a high-margin tenant, the national strategies in technological development and shorter lease terms have caused the conflict that was Seven Star Group planned to demolish the deserted factory complex to build high-tech zone [36]. Between 2003 to 2005 , the conflict led the lowest growth rate of local artists' studio and gallery since 2007 (see Fig 2). A joint effort between the avant-garde artists, local government officials (Li Xiangqun: a former 
artist and then Deputy Member of Beijing Municipal People's Congress) and media has held a range of activities to preserve the art district. To avoid the old factories being demolished, local artists still held the 'Dashanzi International Art Festival' in 2004, which gradually acquired support from domestic scholars and the international media [29]. Moreover, this event has directly created the first international forum of contemporary art in China, which gradually acquired the support by domestic scholars and international media. Subsequently, 798 Art District was recognized as industrial heritage with great historical and cultural value by academia and Chinese government [36].

'The future of 798 Art District' become a national level topic, the 'Eleventh Five-year Plan' listed the Cultural-creative industry as key development industry in Beijing. The 798 Art District obtained legislative conservation and became one of the first cultural districts in 2006 [3]. Afterward, the district gradually matured, the brand and agglomeration effect has become increasingly prominent with the integrity of the local cultural industry chain.

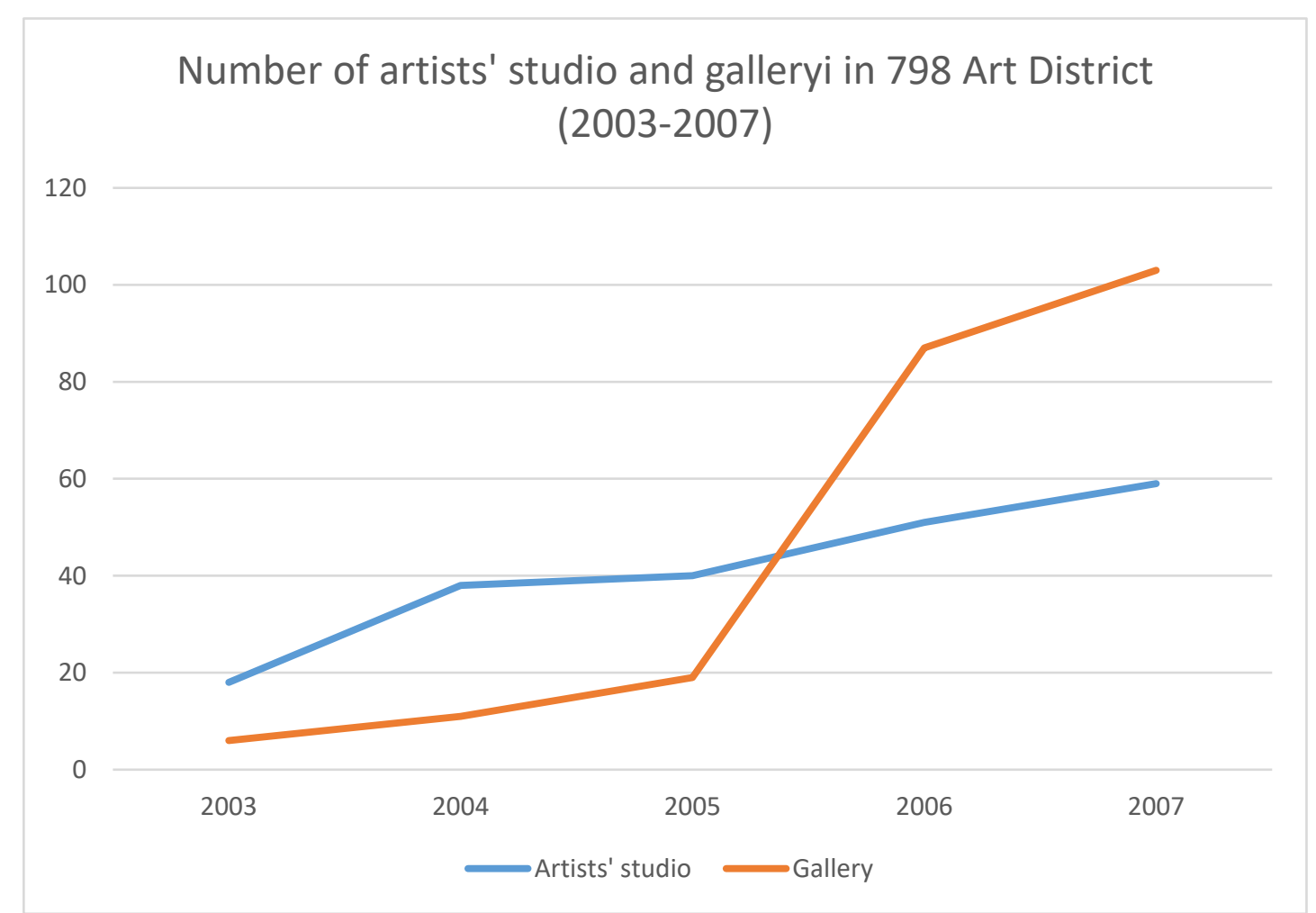

Fig 2. Number of artists' studio and gallery in 798 Art District (2003-2007) [37]

With official certification of government, the local art festivals and events appeared obvious increase trend, and the nature of these festivals and events also shifted from folky to quasi-official. The local cultural creative industry has included painting, sculpture, advertisement, design and drama [38]. With more and more art institutions have settles on 798 Art District, related service industry and cultural entertainment industry also developed which has ensured the development of local tourism. As Fig 3 shows, boutique, cafe, restaurant, bookstore, design and advertisement companies as the 'new blood' ceaseless influx 798 Art District by its brand, and the art district finally formed a shared art exchange space which covering about $600,000 \mathrm{~m}^{2}$ [37]. Especially, the tourism development of 798 Art District has provided assurance for 2008 Global Financial Crisis, during the 2008 Beijing Olympic, 798 Art District became a famous attraction as equal to The Great Wall and Forbidden City [3]. Meanwhile, the site as an important component of urban brand, which also became the platform for big commercial events (i.e., China Fashion Week or an Armani Fashion Show) [39]. Thus, some studies argued that 2008 is the watershed of 798 Art District. Indeed, after the official endorsement, the rental prices consistently increased to more than 4 yuan $/ \mathrm{m}^{2} /$ day (see Figure 5 ), causing the artists to move out [39]. In addition, the number of artists' studios keep a downward trend after 2007, local 
galleries become the major institutions, while the number of Design \& Ad companies and bookstores, catering facilities and boutiques over than artists' studio since the 2010s and keeping a growth trend (see Figure 6) [37]. The commercial atmosphere brought by vast visitors has impacted artistic creation, and the surrounding area gradually appeared property complexes, even some researchers stated 798 Art District had entered the 'gentrification' stage.

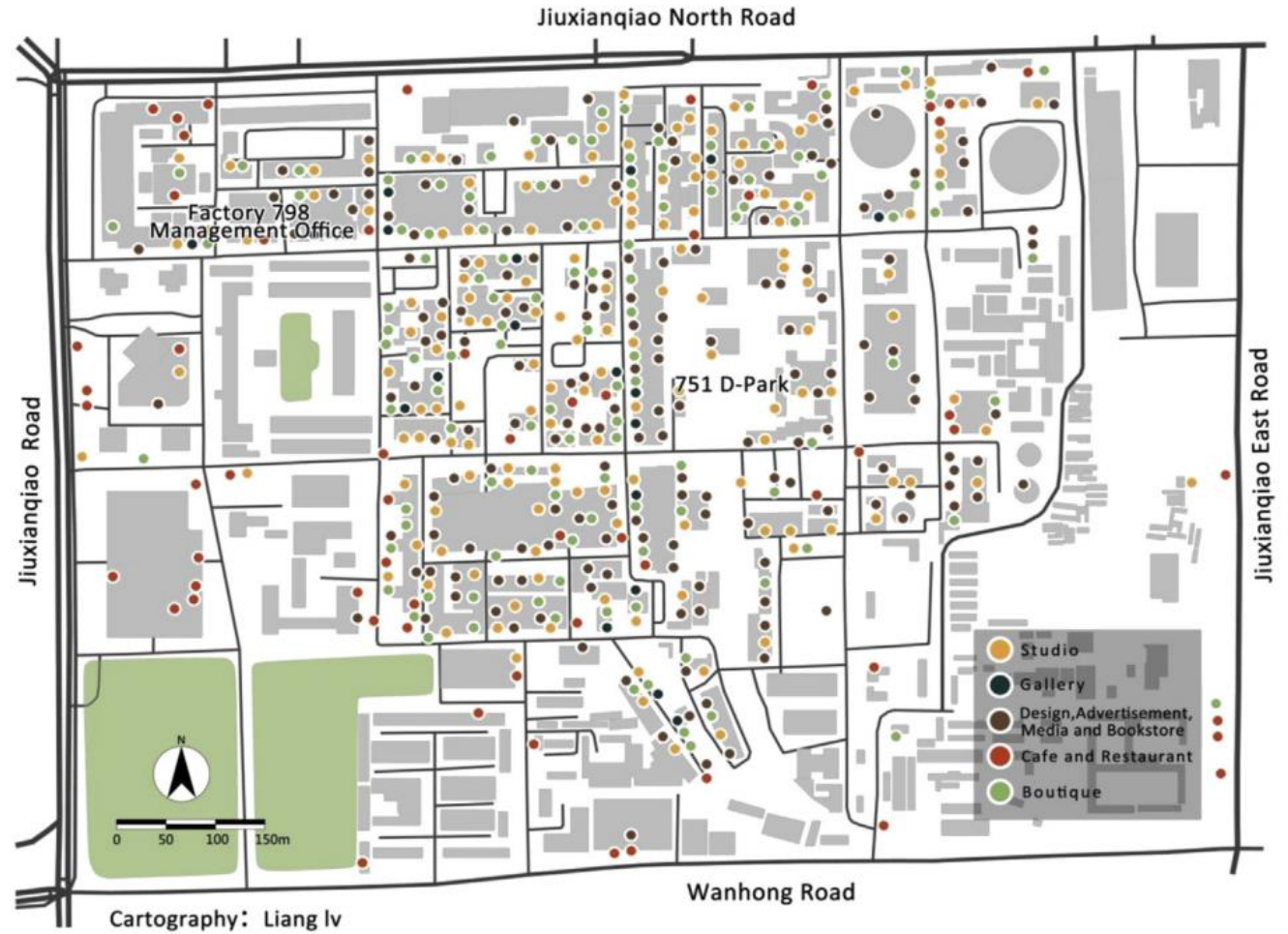

Fig 3. Current layout of 798 Art District [37]

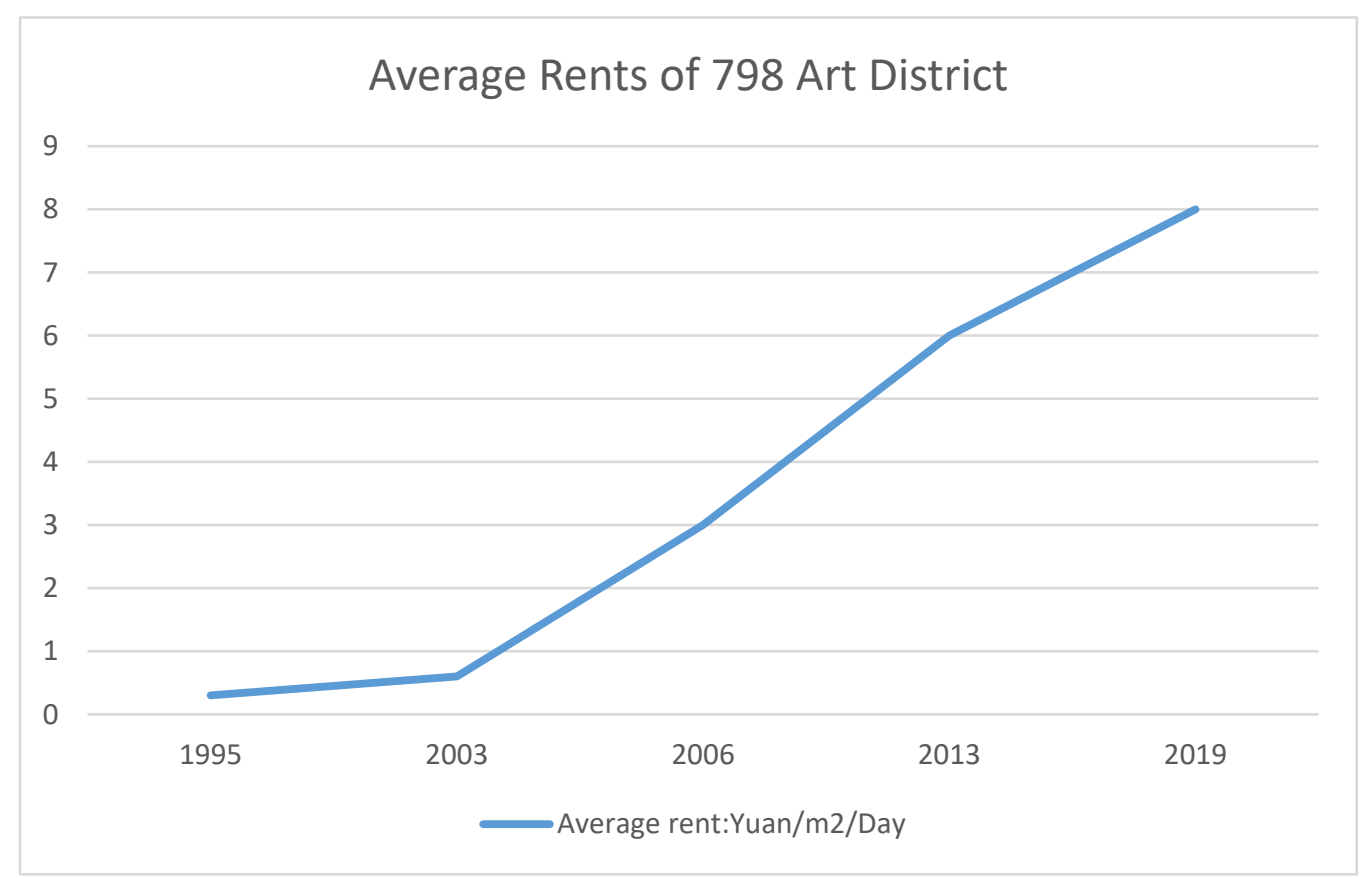

Fig 4. Average rents of 798 Art District [37] [41] 


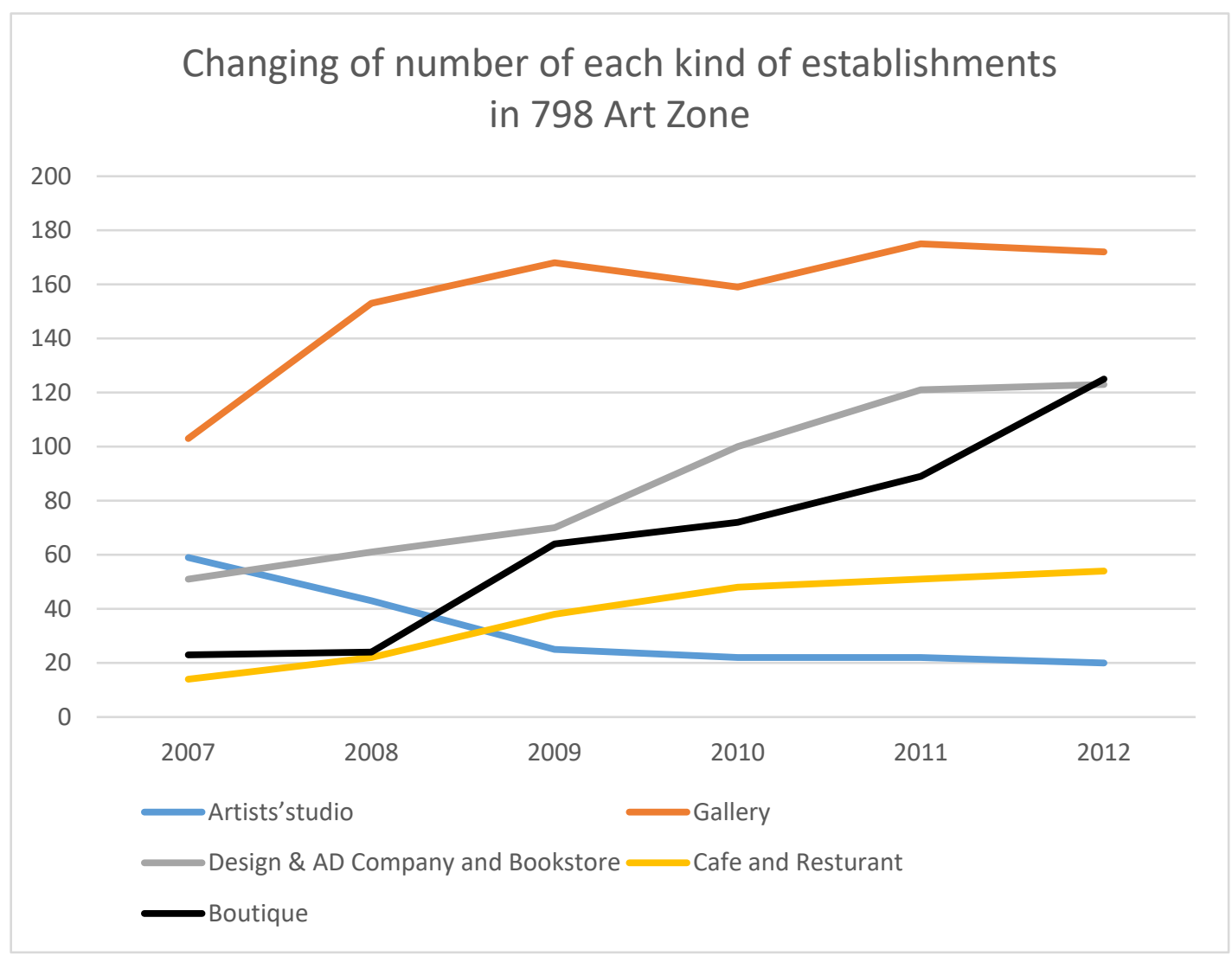

Fig 5. Changing of number of each kind of establishments in 798 Art Zone [37]

\section{Questionnaire-based Site Evaluation}

Lots of research mentioned that the commercialisation process causes the main income of the 798 Art District is relied on tourism, catering and profit-making exhibition. The online questionnaire (Appendix 1) collected data regarding the evaluation of this site. Thematic analysis was used for the answers to the multiple-choice questions and content analysis was used for the answers to the openended question. The thematic analysis was roughly categorized into participants' demographic information (age, transport and information resources), expenditure, After-visit impression and understanding of the art district.

\subsection{Background Information of Participants}

According to the Figure 6, the most participants was concentrated on 18-25 years old $(65.93 \%)$ and 26-39 years old (26.67\%), which suggests the visitors group of 798 Art District is falling into a relatively young group. Correspondingly, the results of the age group have reflected the 'job type' of participants are mainly students $(42.22 \%)$. Moreover, considering the habitation of participants, there are 102 visitors from Beijing, and approximately 1/4 of these participants (35 persons) from the Chaoyang District where is the district 798 Art District belongs.

Based on the word frequency analysis of collected data of Question 4 in the online questionnaire, although the visitors come from all over the country and used various means of transportation, the 'underground' is the most frequently mentioned (75 times) means of transportation, and the underground could keep the transport consuming time not over than an hour (57.5\% participants who chose 'underground' state they could arrive destination no more than $1 \mathrm{~h}$ ). Considering the residence of participants, the underground is the first choice (19 answered 'underground') for non-local tourists (34 persons) when travelling to the 798 Art District after getting off a flight or after a high-speed rail journey. As for local visitors (102 persons), half of these visitors (52 persons) choose the underground 
as main transport mean when visiting 798 Art District. Like the responses of non-local visitors, $60 \%$ of participants (31 persons) pointed out the consuming time will no more than $1 \mathrm{~h}$.

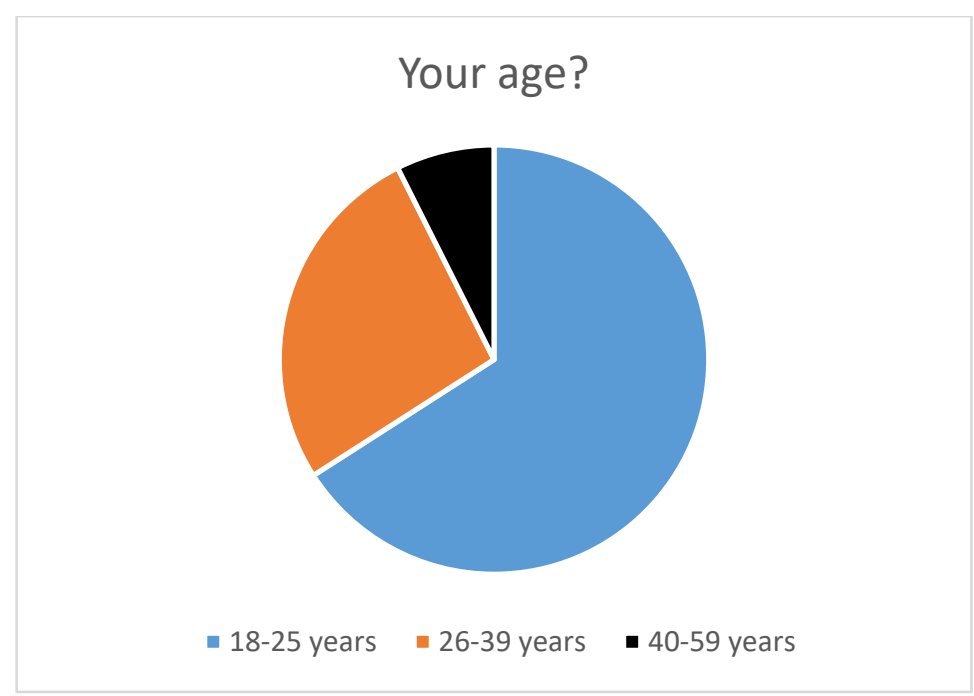

Fig 6. Age group of participants

It was described earlier how the artists and the cultural-creative industry caused the adaptive reuse of local industrial heritage, and the tortuous development trajectory brought reputation to this site. The question has adopted the multiple-choice format and the result (183 answers) as indicated on Fig 7, the awareness of 798 Art District has built on the base of participants' friends (58.52\%) and internet propaganda $(52.59 \%)$. By contrast, the traditional media (newspaper, magazines, TV and radio) has occupied smaller percentage. Eleven participants chose 'Other' and describe the 'close geographic location', 'family members' work type' and 'education experience in history and art' are also important medium to know the site. In addition, as the result of 'initial understanding of 798 Art District' illustration, the oral recommendation and Internet will mainly describe the site as 'contemporary art district' (74.04\%) before the visitors come. In conclusion, the results suggest that the 798 Art District is a contemporary art district that is popular with people aged 18-39 years. Word of mouth and the internet are the main sources of its reputation, and the underground is the main method of transport for its visitors.

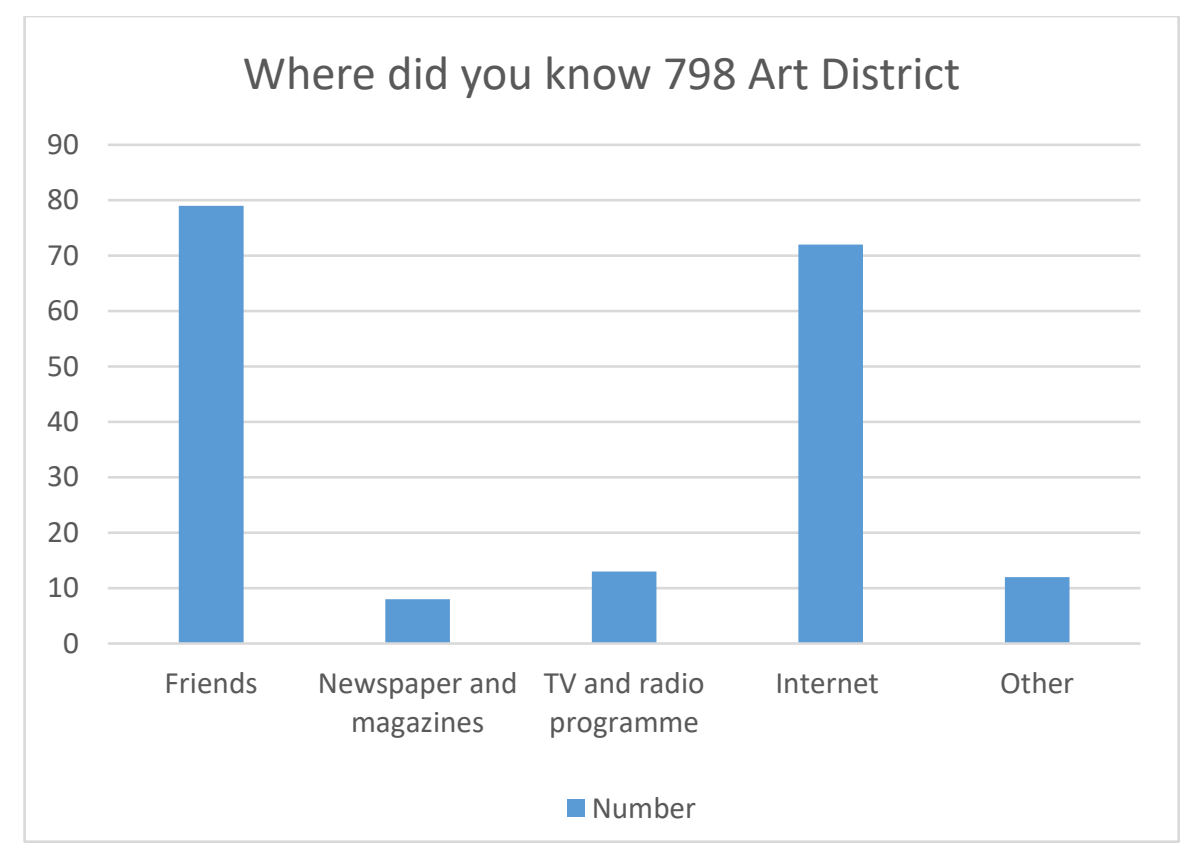

Fig 7. Information resource 


\subsection{On-site Expenditure}

According to Fig 8 and 9, it can be seen that the majority of participants (114 persons) choose 'Casual visiting', which include relaxing mind, taking photos and eat and drink. Seventy participants said that they came to visit the local exhibition hall to enjoy the artistic atmosphere in purpose or random. The main activities will reflect the visitors' most interesting elements in the art district. The art-related facilities (Gallery and Artists' studios for 31.11\%, Creative shops and Art shops for 23.7\%) have accounted for over half of visitors' all preferences. Additionally, 33.33\% of respondents stated they are mainly fascinated by local industrial-style buildings and sculptures. Before analysis the consuming behavior, near $70 \%$ of participants said their cost is voluntary. Based on the findings of visitors' results, the art-related expenditure $(55.55 \%)$ ranks a big part of all visitors' costs in the art district (Gallery/Exhibition tickets for $33.33 \%$, and Art/Design product for $22.22 \%$ ). Also, the catering industry is the most significant component (40\%) of their cost, which exceeds either of element of art-related expenditure (see Figure 10). As Figure 11 shows, the average cost has illustrated under 300 Yuan $(91.11 \%$ ) as the biggest part, especially, $67.41 \%$ of participants could control their cost under 200 Yuan.

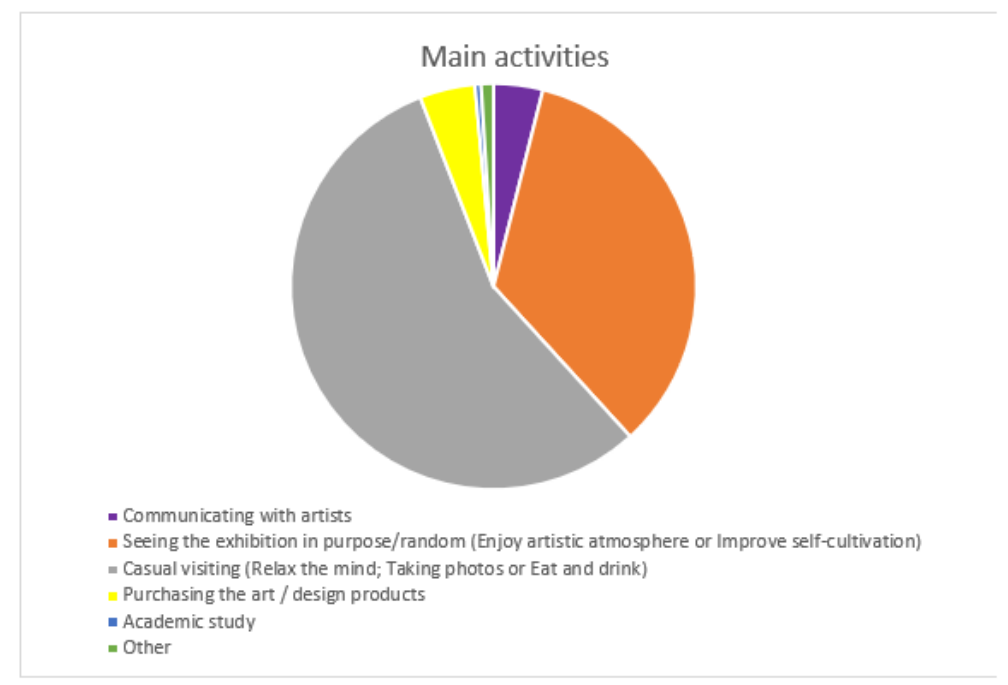

Fig 8. Visitors' main activities

\section{Which element you are most interesting}

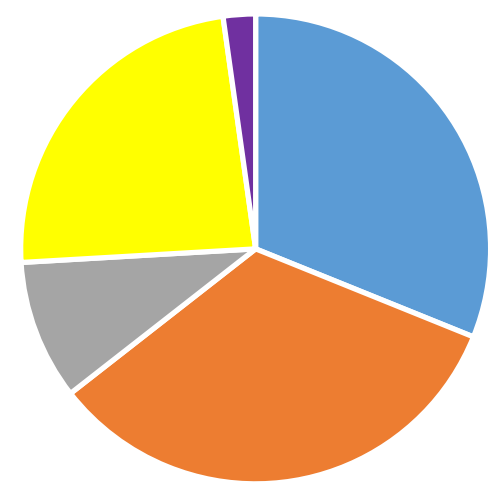

$$
\begin{array}{ll}
\text { - Gallery and Artists' studios } & \text { - Industrial style buildings/sculptures } \\
\text { = Restaurants and Bars } & \text { Creative shops and Art shops }
\end{array}
$$

Fig 9. Most interesting elements of visitors 


\section{The main source of visitors' expending}

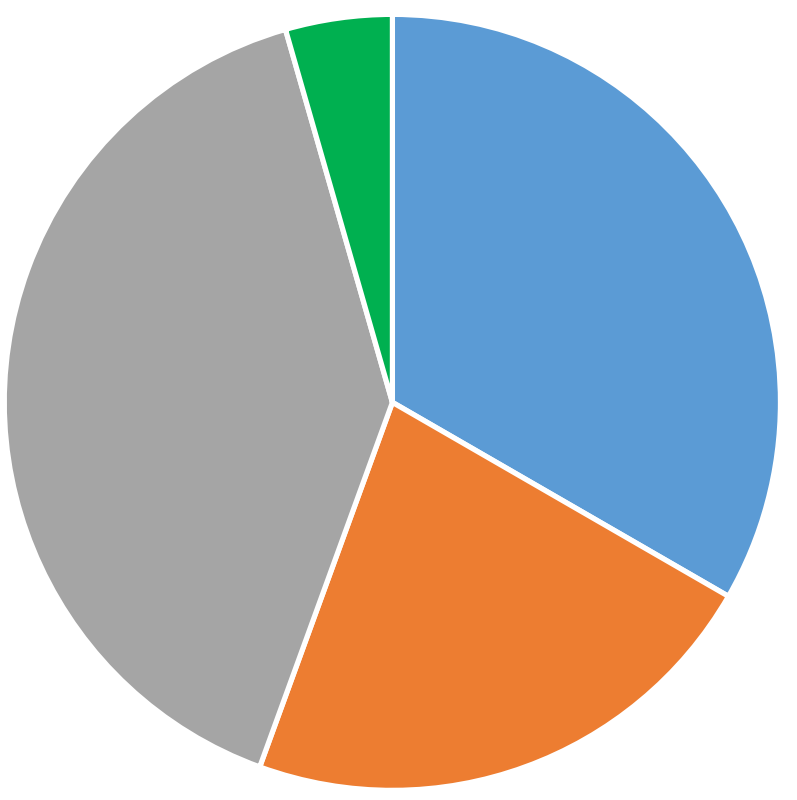

- Gallery/Exhibition tickets = Art/Design products (Include souvenirs) ॥ Food and drink - Other

Fig 10. Main source of visitors' cost

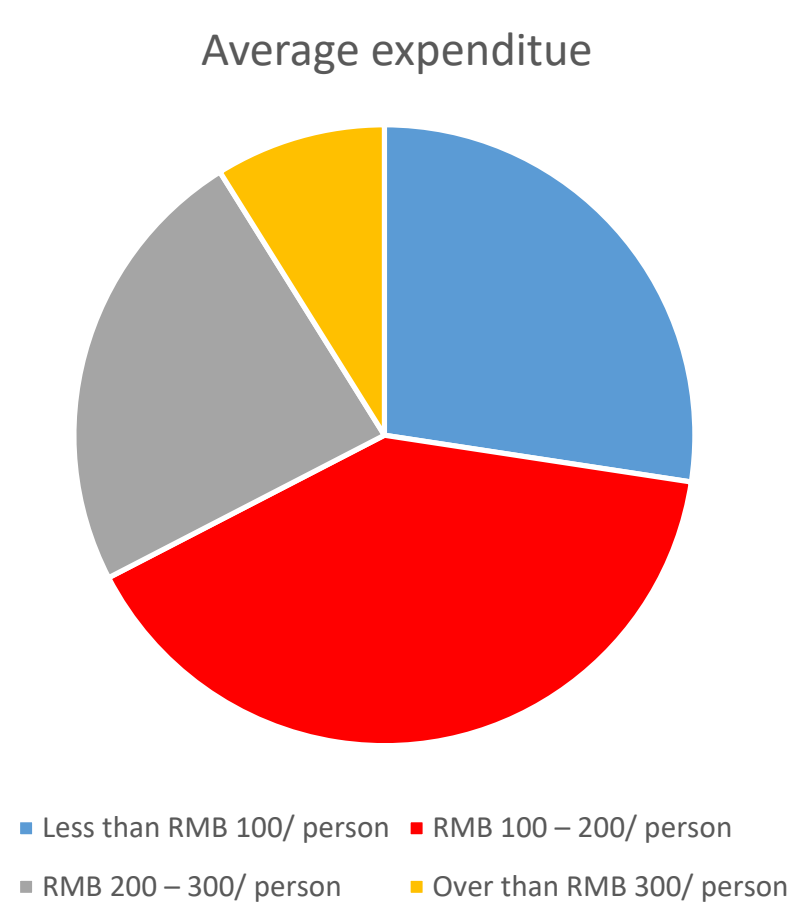

Fig 11. Average expenditure in 798 (1 Chinese Yuan=0.14 Dollar ((US)/0.11 Pound (UK))

\subsection{After-visit Impression and Understanding}

\subsubsection{Industrial Heritage}

Industrial heritage as the roost of local reuse activities, which experienced a series of transformations. Over half of the visitors ( 74 persons) regard local industrial heritage as the most representative element in this site (see Figure 12). Additionally, the recognition of local industrial heritage is principally reflecting from the preservation of the exterior architectural style of original 
industrial buildings (52.59\%), and the industrial sculpture, new observation deck and interior reconstruction of industrial buildings are occupied a similar ratio (near 15\%). As Figure 13, the main role of local industrial heritage primarily plays a witness for the urban industrialisation process $(43.7 \%)$, and the landscaped function of the urban image $(24.44 \%)$ and residential and work nature for artists $(22.22 \%)$ also play equally important role. Thus, local industrial heritage is an impressive element for visitors that reflect in the preservation of the exterior style, and the remoulding of interior structure and the establishment of service facilities guide the development of Cultural-creative industry and tourism. Moreover, the site's historical value is its most important aspect, followed by its economic and aesthetic value.

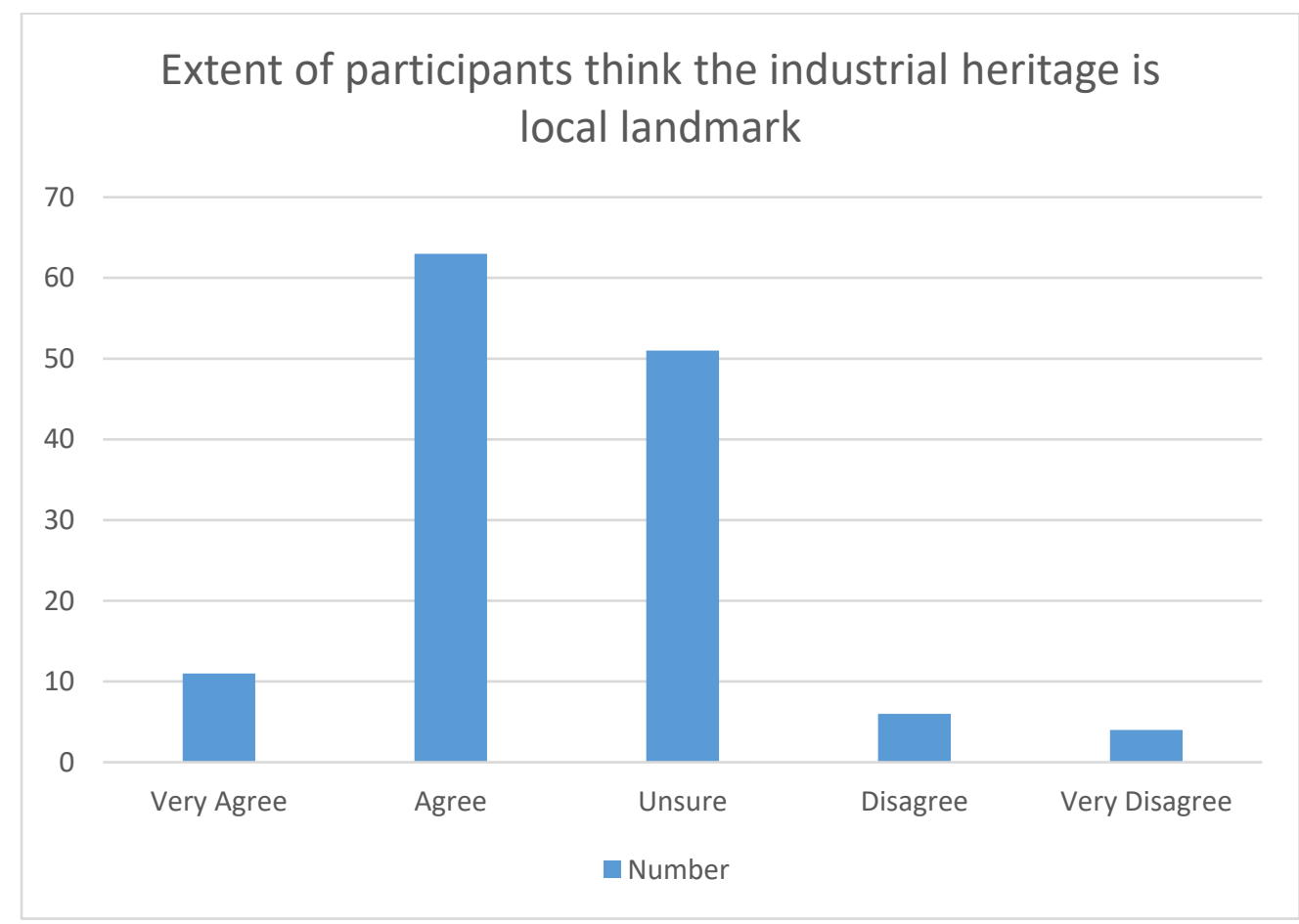

Fig 12. Identity of the industrial heritage

Role of industrial heritage

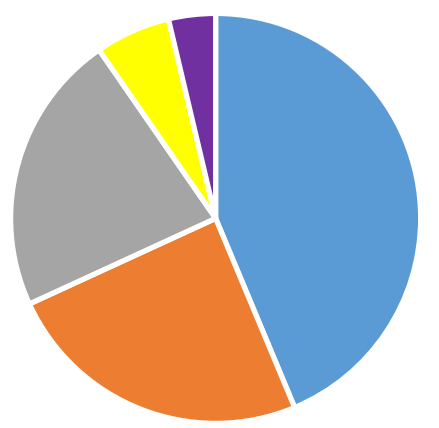

- Witness of urban industrialization process

- Unique urban landscape

- Home or workplace of local artists/designers

- Case for heritage education

- Other

Fig 13. Role of local industrial heritage 


\subsubsection{Art District}

In terms of development of the site was promoted by Cultural-creative industry, the most creative site elements are mainly reflecting in artworks and art form in outdoor space ('Street Graffiti and Sculpture' for 40\% and 'Industrial Style Building' for 25.93\%). In comparison, the level of creativity in local art exhibits and design products are mediocre (20.74\% and $8.89 \%$ respectively). After the visit of the cultural district, the participants' main returns are reflected in aesthetic promoting (37.04\%), and the cultural (26.67\%) and fashion (24.44\%) trend perception almost is the second important that account for similar percentage (see Figure 14). Moreover, with the evaluation for the value of the art district, in Figure 18, the biggest percentage of participants (90 persons) express the dominating value is a platform for art-related workers (see Figure 15). This was followed by the 798 Art District enhancing public interest in art and culture (59 persons) and providing a paradise for industrial heritage (49 persons). In contrast, the value at a larger level could not be easily recognized by participants. Specifically, the participants who regard the art district as the multicultural exchange platform (15 persons) and impact on city image (12 persons) only occupy near $20 \%$. Ultimately, 90 visitors show their travel experience in the site should be classified into 'Leisure and sightseeing'. Therefore, according to above results, the shaping of public space and conservation of industrial buildings in art district are magnet to visitors. From an overall perspective, this site is being deemed as a large urban public space, which both accept the art groups and tourists. Aesthetic view, cultural and fashion trend is the most significant three elements for visitors' gain. Also, the value of the site could be classified as the intuitive cognition of the cultural district, which provides a platform for art/cultural exchange and heritage preservation.

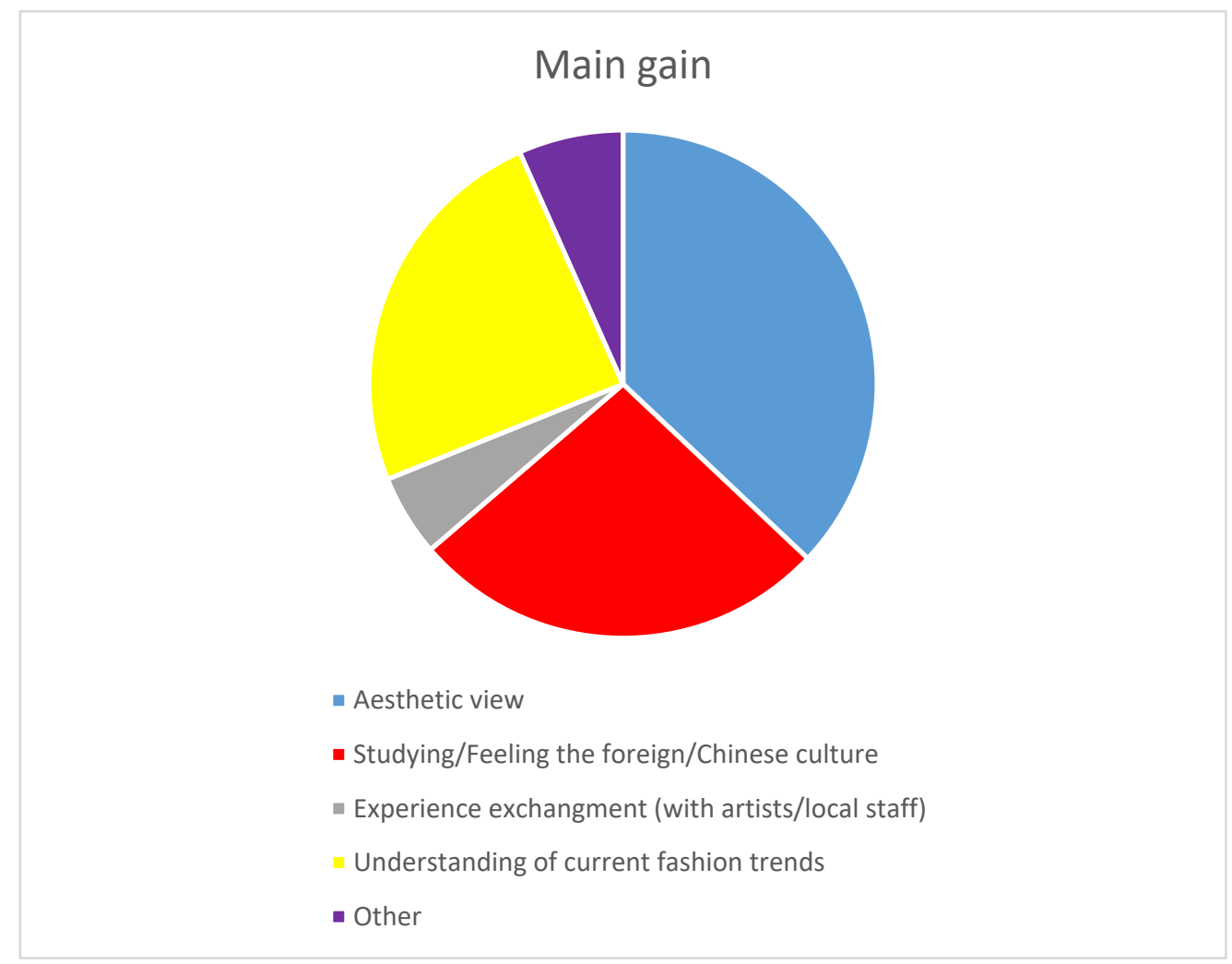

Fig 14. Main returns for 798 Art District

\subsection{Issues and Suggestions}

First, according to the research statistics in Figure 16, the commercialisation of the district is a recognised issue by visitors $(n=82)$ that leads to high prices. Moreover, lacking related introduction and explanation of local artwork will limit their understanding and gain over there. For the public space in the art district, almost an equal number of visitors pointed out the original industrial buildings' 
appearance damage (26 persons), disordered environmental condition (27 persons) and inadequate facilities ( 23 persons) are main management issues which will influence the image and visitors' impression of the art district.

\section{Value of 798 Art District}

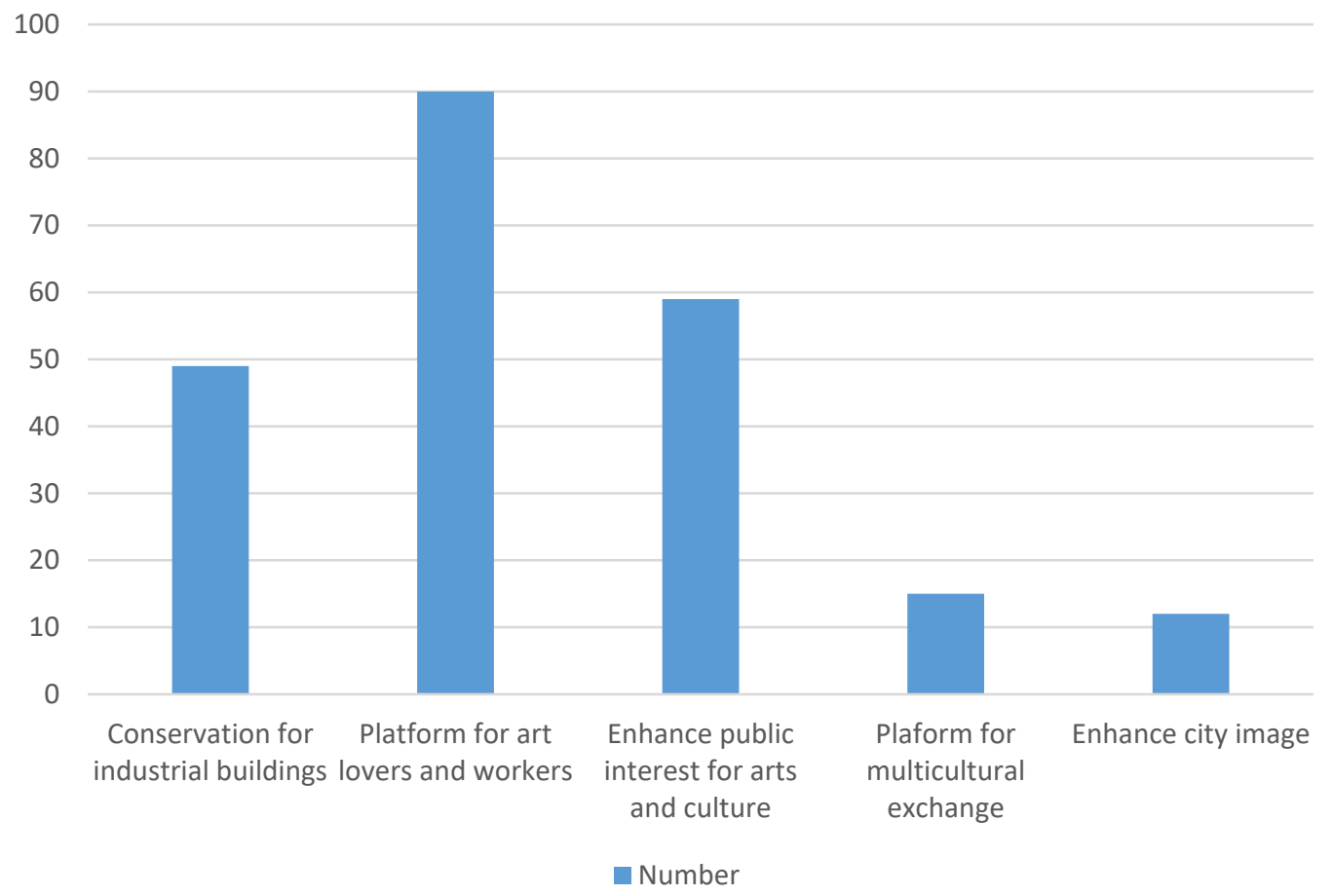

Fig 15. Value of the 798 Art District

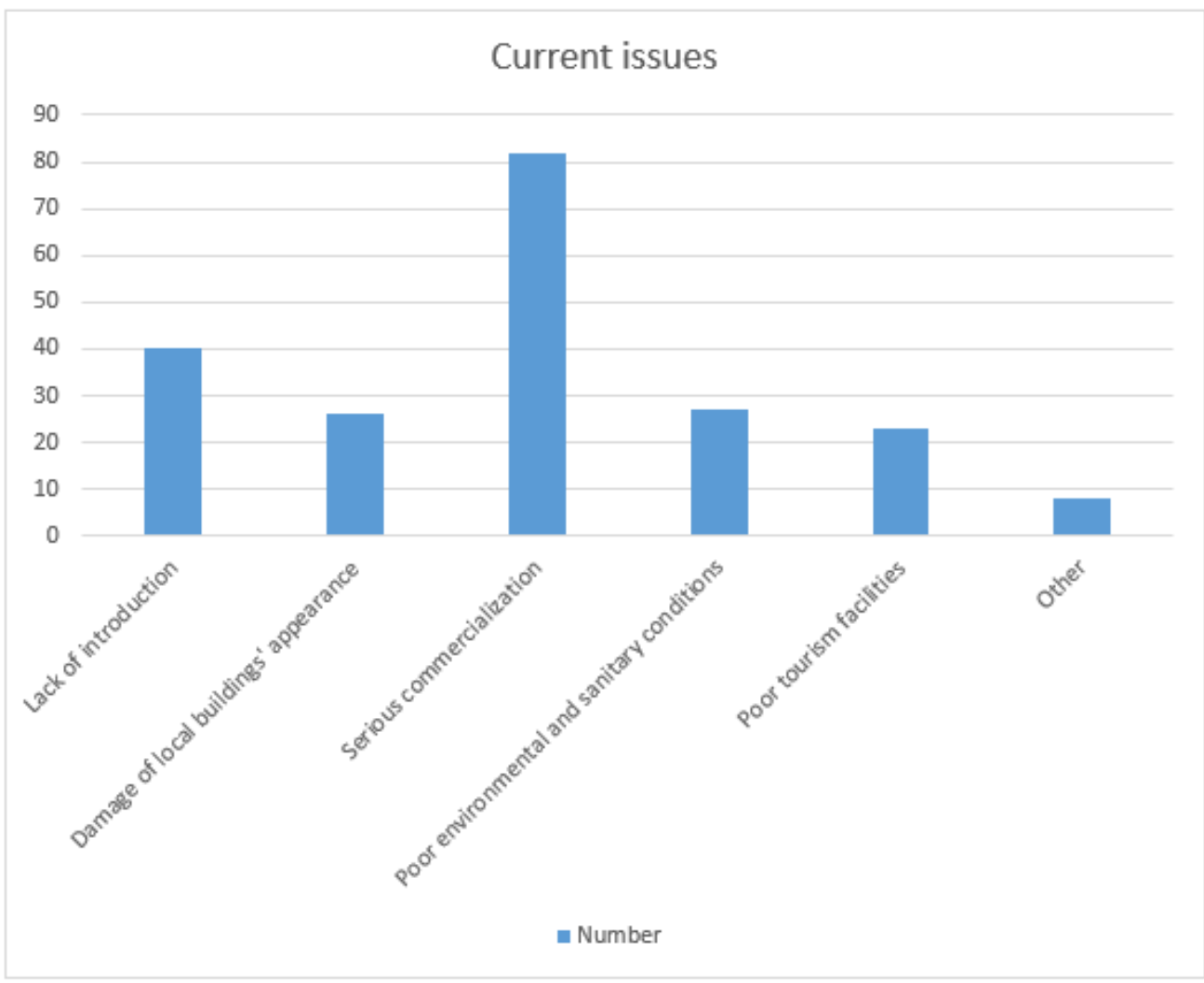

Fig 16. Current issues in the site 
Therefore, based on the valid answers (75 copies) for the opened-end questions, the code analysis shows mostly participants demonstrate the future development process of the site should control the level of commercialisation. Meanwhile, they mentioned that the current development situation of 798 Art District lacks uniqueness. To be specific, local shops, design products and souvenirs are similar or same as other domestic tourist attractions, even they can buy it for online shops. As to the local exhibitions, some participants who come here for "Watching the art exhibition' hope to enjoy 'real art' rather than commercial-purpose exhibitions or Internet celebrity photo activities. Also, some participants said they hope to see more diversified art in the 798 Art District. On the one hand, they want to know more foreign cultures and previous industrialisation process through local activities. On the other hand, visitors strongly expect the experiential and interactive art form (i.e., glass furnace, pottery and oil painting) to understand the manufacturing operation of artworks and design products. In terms of the layout and service of art district, the absence of the introduction about small-scale exhibitions and industrial heritage will influence the understanding of relevant factors. In addition, the large parking-lot has occupied the space within the park lead the layout and environment disordered, and the mini map and incomplete service facilities also will affect tour experience for visitors (i.e., poor photo effect, get lose, excessive expenditure).

\section{Discussion and Conclusion}

According to above research about 798 Art District, the site has successfully integrated heritage conservation and Cultural-creative industry, which leading to improved market recognition, social influence and international reputation. Although the development trajectory is flexural and the current condition is controversial, the roles in cultural art and heritage are conspicuous. Specifically, the results of the questionnaire show the site could have great appeal to younger age groups (18-25), especially students' group, and local brand awareness is benefited from the recommendations of previous visitors' and Internet. Local consuming behaviors have greatly verified the commercialisation trend. Tourism-related industry and facilities (catering and art stores) have occupied the most important expenditures, which shows the development priority has shifted from 'cultural production' to 'cultural consumption', and this trend has largely influenced the creativity. Thus, based on visitors' expressions, the elements of aesthetic and cultural perspective are composed their main returns, but fewer experiential and educational interaction caused their experience in 798 Art District to be more like recreation and entertainment. From the findings of the art district, the visitors' understandings mostly recognised the practical significance of culture and heritage, however, the broader significance of urban perspective is not easily be appreciated. From the findings of local heritage, the preservation of buildings' facade, reusing of their interior spaces and newly built public facilities (industrial sculptures and observation desk) are three major approaches to preserving local heritage. These approaches have also made the industrial heritage become the element that most visitors are interested in, even local landmark. Moreover, the top-three roles of local industrial heritage are respectively embodied historical, aesthetic and economic value. Although these three values have created considerable economic income and led to urban redevelopment, a relatively single utilisation mode caused space wasting and the absence of cultural sustainability. To a large extent, the above assessment has determined that local development predicament is showing on positioning deviation and commercialisation trend. First, this area was incipiently focused on pure artistic creation, and changed to an agglomeration of art, commerce, recreation and tourism. The consequent commercialisation trend has not improved the local artistic creativity, although brand reputation has taken international cooperation, the strong dependence on local creativity is becoming a prominent shortcoming. Next, the commercialisation trend also influenced the quality of the local Cultural-creative industry: the revenue-oriented institutes, companies and stores (who can afford high rent prices) with art or cultural signboards are gradually changing the nature of the art district. 


\subsection{Discussion of Literature and Findings}

To sum up the research findings for Beijing 798 Art District and literature review for Shanghai M50 and Guangzhou Xinyi International Club, the cultural policies, reusing the industrial heritage and land-use reform played the essential roles in their respective development trajectory. As Table 1 shows, the exploration of adaptive reuse of industrial heritage in different cities will illustrated various trajectory. Guangdong Province as the window for 'Reform and Opening up', the Special Economic Zone has taken the commercial opportunities to local society and cities, adding the supportive policies of local government, the layout and the composition of Cultural-creative industry in Xinyi International Club is economic purpose. By contrast, the formation of Beijing 798 Art District and Shanghai M50 was experienced spontaneously gather of creative class and the collaboration of creative class, public-private institutes and local authorities. Although the Bottom-up development process is full of twists and turns, following international focus, public awareness and city branding to promote the preservation and transformation of art district [24]. Moreover, in their respective histories, for Beijing 798 Art District, the dual role of artists has enlightened the nascent development and preservation of the site, and the M50 is emphasized on the relationship with land-oriented groups (urban planners and conservationists) to launch related policies [41]. Exploring the status and development issues of these sites (Table 2), the three sites is facing the sustainability issues. The topdown development model will present social isolation and low brand awareness, since lacking of creative class make it looks like a cluster for cultural elites. In comparison, relatively compact layout in M50 cause less room for development, and lacking the social space and the connection with surrounding communities cause the art district seems too abrupt with residence, and that will limit the local vitality. Although similar commercialisation trend emerged in M50, which also caused cultural consumption become the mainstream, the image of M50 is relative ordered and artistic (pedestrian-friendly, waterfront area and moderate price) [22]. By contrast, as the famous avant-garde art district in China, 798 Art District had faced serious gentrification trend. On the one hand, local creative class have not the right to participate the operation and management, and with their evacuation has influence the sustainability in cultural and social perspective. On the other hand, cultural consumption and catering has occupied the biggest rate of expense made 798 Art District like a tourist attraction, the large visitor volume will provide negative effects to creativity, since the artworks need to conforms the taste of the general public.

Table 1. Comparison of three art districts

\begin{tabular}{|c|c|c|c|c|}
\hline Cases & Timeline & Triggers & \begin{tabular}{|l|} 
Special \\
Factors
\end{tabular} & Summary \\
\hline $\begin{array}{l}798 \quad \text { Art } \text { District } \\
\text { (Beijing) }\end{array}$ & $\begin{array}{l}\text { End of the } 1980 \mathrm{~s} \text { : } \\
\text { Factory } 798 \text { Production } \\
\text { ceased } \\
\text { 1995: First artists arrived } \\
\text { 2000: Establishment of } \\
\text { Seven Star Group } \\
\text { 2004: Dashanzi } \\
\text { International Art Festival } \\
2006 \text { : Official } \\
\text { endorsement as } \\
\text { 'Creative Industries Park' }\end{array}$ & 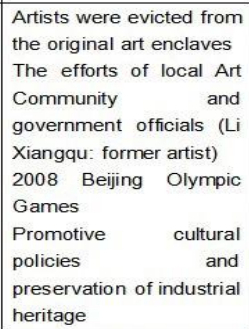 & 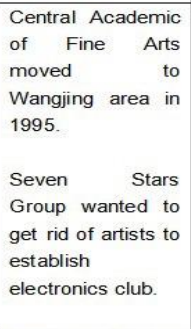 & $\begin{array}{l}\text { Artists' group aggregated } \\
\text { spontaneously } \\
\text { (Bottom-up). } \\
\text { Government and } \\
\text { State-owned enterprise for } \\
\text { mutual operation and } \\
\text { management }\end{array}$ \\
\hline M50 (Shanghai) & 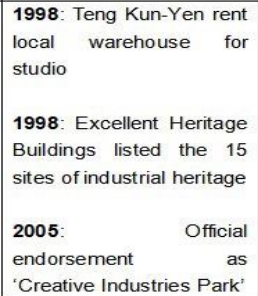 & 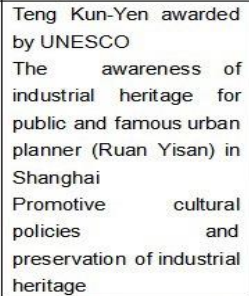 & $\begin{array}{l}\text { The migration of } \\
\text { the artists from } \\
\text { West Suzhou } \\
\text { Road. } \\
\text { Media resource } \\
\text { and international } \\
\text { concern made the } \\
\text { art district will not } \\
\text { be demolished }\end{array}$ & $\begin{array}{l}\text { Artists' group aggregated } \\
\text { spontaneously } \\
\text { (Bottom-up). } \\
\text { State-owned enterprise is } \\
\text { the investor and manager } \\
\text { of site }\end{array}$ \\
\hline $\begin{array}{l}\text { Xinyi International } \\
\text { Club (Guangzhou) }\end{array}$ & $\begin{array}{l}\text { 2004: Invested by } \\
\text { Guangdong Minghuiyuan } \\
\text { real estate agency } \\
\text { 2007: Opened to public }\end{array}$ & $\begin{array}{l}\text { Policy for 'Suppress the } \\
\text { secondary industry and } \\
\text { Develop the tertiary } \\
\text { industry' }\end{array}$ & None & $\begin{array}{l}\text { Government-led } \\
\text { development (Top-down). } \\
\text { Invested and built by real } \\
\text { estate agency }\end{array}$ \\
\hline
\end{tabular}


Table 2. Development issues of three sites

\begin{tabular}{|c|c|c|c|}
\hline Cases & Area & Issues in social aspect & Issues in cultural aspect \\
\hline Beijing 798 Art District & $640,000 \mathrm{~m}^{2}$ & $\begin{array}{l}\text { The participation of } \\
\text { artists' group in } \\
\text { management and } \\
\text { operation is low } \\
\text { Tourists are local major } \\
\text { visitors }\end{array}$ & $\begin{array}{l}\text { Commercialization cause } \\
\text { local artists moving out } \\
\text { Artworks and design } \\
\text { products lack of peculiarity }\end{array}$ \\
\hline Shanghai M50 & $24,000 \mathrm{~m}^{2}$ & $\begin{array}{l}\text { Lack of connection with } \\
\text { surrounding } \\
\text { neighbourhood }\end{array}$ & Lack of public space \\
\hline $\begin{array}{l}\text { Guangzhou Xinyi } \\
\text { International Club }\end{array}$ & $25,000 \mathrm{~m} 2$ & Social isolation & $\begin{array}{l}\text { Lack of artists' group and } \\
\text { community }\end{array}$ \\
\hline
\end{tabular}

\subsection{Recommendations}

Nowadays, the Cultural-creative industry has been used by most cities as a significant catalyst to promote the urban regeneration, especially for discarded urban district. From the heritage perspective, industrial heritage has effectively extended the original architectural texture and that become the valuable urban space, the injection of Cultural-creative industry had taken the vitality and economic income. From the development process of 798 Art District, with the collaboration with government and state-owned enterprise, the theme positioning, subjects and formats of development are progressive diversification. However, based on the research findings, although the development model is worth learning that creating remarkable achievements, the negative effects from the sustainability issues are needs to be addressed in the future development stage.

\subsubsection{Heritage Education and Cultural Base}

Based on the secondary data study and the assessment about the industrial heritage in the questionnaire, 798 Art District has provided a good case for heritage adaptive reusing which is a sustainable way to preserve the industrial heritage. However, the visitors' understanding and impressions are showing the local industrial heritage only reflected their historical, aesthetic and economic value. The development process also should focus on the utilization of the education and spiritual value of heritage. Firstly, the preservation of old industrial buildings' appearance and the built of heritage-related public art should be continued, which could create a better artistic atmosphere. Moreover, local agency and event organisers could organise the relevant exhibitions and experiential activities for former industries, which could let visitors easily know the history of the art district and national electronic industry. Also, the partnership between the 798 Art District and education institutions should be established, and the 798 Art District should set aside specific space to accommodate educational activities.

(1) Diversified development of art form

It is been discussed at the 'Issues and suggestions and former 'Discussion' part, the art form is lacking uniqueness and tends to cater to the taste of mass. Overall, brand marketing has gone beyond content marketing, specifically, visitors will be attracted by the reputation of 798 Art District, but local products and souvenirs are like those in other tourist attractions. Thus, the proper strategy for content marketing will powerfully attract more art collectors and lovers. In specific, the experiential 
and interactive art form (i.e., glass furnace, pottery, oil painting and public art festival) could attract more visitors to enjoy the artistic atmosphere and let them understand the manufacturing process of artworks and design products easily, especially for non-art lovers and amateurs. Additionally, to preserve the cultural creativity, art trade, creative performance, animation design and game production could involve future development to achieve industrial and consumption diversification.

(2) Improve the management system

According to local issues and visitors' suggestions, the commercialisation trend and chaotic layout are reflecting the management issues. As for the commercialisation phenomenon, local administrators should establish a hierarchical classification system and corresponding preferential policies for local Cultural-creative institutes. On the one hand, the Cultural-creative industry with independent innovation or independent intellectual property acquires the safeguard. On the other hand, these approaches will largely limit the size and number of commerce and catering. In addition, professionals with expertise in heritage and planning are crucial, they could provide technical and value assessment to development model, and for completing the infrastructure of tourism function to realise sustainability development.

\section{Conclusion}

For the findings of this study, as the forerunner of Chinese Cultural-creative district, 798 Art District could represent a kind of cooperation between heritage reuse and new economic model. According to the secondary resource studying, industrial heritage possesses important intrinsic and utilitarian value, especially the existed building texture provides the living-space for the Culturalcreative industry, whereas the Cultural-creative industry brings new vitality to these buildings and urban zones. As for the development process, the spontaneously formed by creative class (low rent) and government-led planning (high rent) was severally appeared in early and late stage of the development process. With the industry chain gradually mature and complete facilities in art district, the 798 Art District has become the large-scale comprehensive Cultural-creative industry park, and the following commercialisation progress has influenced the composition, cohesion and scale of local creative class. The development of tourism caused the industry assimilation also to become a considerable factor to impact local sustainability. Therefore, with the globalisation trend, the mix model of the Cultural-creative industry and industrial heritage still possess positive prospect, finding a feasible 'development-management-operation' pattern to enhance the sustainability and establish integrated and well-organised facilities for Chinese Cultural-creative districts are impending.

\section{References}

[1] Hall, P. Creative cities and economic development. Urban studies. Vol 37(2000) No.4, p. 639-649.

[2] Du Gay, P. and Pryke, M. eds. Cultural economy: Cultural analysis and commercial life. SAGE. (2002).

[3] Chong, R. Wei, X., and He, Y. Research on the Development of Cultural and Creative Industry Park-A Case Study of 798 Art District in Beijing. Journal of Chifeng University (Soc. Sc). Vol 40 (2019) No. 4, p. 66-68 [In Chinese].

[4] Mieg, H. A. Sustainability and Innovation in Urban Development: Concept and Case. Sustainable Development. Vol 20 (2012), p. 251-263.

[5] Chen, H. Chinese culture creative industry: development actuality and prospect. Economic geography. Vol 28 (2008) No.5, p. 728-733 [In Chinese].

[6] Hesmondhalgh, D. The Cultural Industries. SAGE. (2013).

[7] Xiao, Y.Y. et al. Shaping Cultural and Creative Space: Beijing as a case study. Sydney eScholarship Home Arts and Social Sciences Department of Media and Communications Proceedings of the 19th International Symposium on Electronic Art. ISEA2013, Sydney (122). 
[8] Lu, L. and Etzkowitz, H. Strategic challenges for creating knowledge-based innovation in China: Transforming triple helix university-government-industry relations. Technology Management in China. Vol 3 (2008) No.1, p. 5-11.

[9] Pietro, L. D. et al. Heritage and identity: technology, values and visitor experiences. Journal of Heritage Tourism. Vol 13 (2018) No. 2, p. 97-103.

[10] Harrison, R. Understanding the Politics of Heritage. Manchester University Press (2010).

[11] Nuryanti, W. Heritage and postmodern tourism. Annals of Tourism Research. Vol 23 (1996) No.2, p. 249260.

[12] Information on: https://whc.unesco.org/.

[13] Loures, L. Industrial Heritage: the past in the future of the city. Wseas transitions on environment and development. Vol8 (2008) No.4, p.687-696.

[14] Fouseki, K. and Sakka, N. Valuing an Ancient Palaestra in the Centre of Athens: The Public, the Experts, and Aristotle. Conservation and Management of Archaeological Sites. Vol 15 (2013) No.1, p. 30-44.

[15] Zhang, D. et al. Value of Industrial Heritage and Its Conservation. Journal of Northeastern University (Social Science) 9 (2007) No.1, p. 16-19.

[16] Baruti, X., Mezini, L. and Nepravishta, F. Regeneration of industrial heritage sites a potential for sustainable development. Napoli: Faculty of Architecture and Urbanism (FAU), Polytechnic University of Tirana, Italy (2017), p.302-308.

[17] Wang, J. and Rong, J. Regeneration and redevelopment of historic industrial buildings and sites. World architecture. Vol 6(2001) No.1, p.17-22 [In Chinese].

[18] Severcan, Y. C. and Barlas, A. The conservation of industrial remains as a source of individuation and socialization. International journal of urban and regional research. Vol 31 (2007) No, 3, p. 675-682.

[19] Huang, H. Cultural Planning: Urban Integral Development Strategy Based on Cultural Resource. Beijing: China Construction Industry Press. (2010) [In Chinese].

[20] Zhang, A. Placing Arts Districts within Markets: A Case Study of 798 Arts District in Beijing. International Journal of Urban and Regional Research. Vol 43 (2019) No. 6, p. 1028-1045.

[21] Sepe, M. Place identity and creative district regeneration: the case of 798 in Beijing and M50 in Shanghai. Journal of Faculty of Architecture, Middle East Technical University. Vol 35 (2018) No, 2, p. 151-171.

[22] Wang, J. 'Art in capital': Shaping distinctiveness in a culture-led urban regeneration project in Red Town, Shanghai. Cities. Vol 26 (2009), p. 318-330.

[23] Gu, X. The art of re-industrialization in Shanghai. Culture Unbound. Vol 4 (2012), p.193-211.

[24] Shen, Z. et al. Sustainability issues in the industrial heritage adaptive reuse: rethinking culture-led urban regeneration through Chinese case studies. Journal of Housing and the Built Environment. Vol 33 (2018), p. 501-518.

[25] Ye, L. Urban regeneration in China: Policy, development, and issues. Local economy. Vol 26 (2011) No,5, p. 337-347.

[26] Waibel, M. Zielke, P. and Altrock, U. The Development of Creative Spaces in China: The Case of the Pearl River Delta. Pacific New. Vol 37 (2012), p. 29-31.

[27] Li, P. Study on Industrialization in the Guangzhou Region Creative Industry Park, Landscape Architecture Design. Master Dissertation, Department of Landscape Architecture, South China University of Technology, China (2013).

[28] Fan, R. Modern Economic Geography of North China and Mongolian Plateau. In: Wu, S. and Dai, A. eds. Modern Economic Geography of China. Vol.7 ECNU Press (2011).

[29] Dekker, R. 798 Art Zone Beijing: Site of 'Cultural Revolution' or Showpiece of City Marketing? Master Thesis, MANAMA Conflict and Development, Faculty of Political and Social Science, University Gent, Belgium (2012).

[30] Ding, L. and Su, S. Elementary Research on Exhibition Space in the Study of Old Industrial Plant Rebuilding in Beijing - Taking the 718 Joint Factory -- UCCA Hall for Example. Chinese Overseas Architecture. Vol 7 (2015), p. 90-92.

[31] Huang, R. Beijing 798: Reflections on a 'Factory' of Art'. Sichuan Fine Arts Publishing House. (2008). 
[32] Elzen, V. S. Dragon \& Rose Garden: Art and Power in China. Blue Kingfisher. (2010).

[33] Fang, C. The urbanization and urban development in China after the reform and opening-up. Economic Geography. Vol 29 (2009) No,1, p. 19-29 [In Chinese].

[34] Alder, S. et al. The Effect of Economic Reform and Industrial Policy in a Panel of Chinese Cities. 2013 Meeting Papers 1309, Society for Economic Dynamics.

[35] Chen, H. Complexities of Chinese Contemporary Art. Master's Projects and Capstones, University of San Francisco, The United States of America. (2018).

[36] Liu, X. et al. Art villages in metropolitan Beijing: A study of the location dynamics. Habitat International. Vol 40 (2013) p. 176-183.

[37] Yin, Y. et al. The 798 Art District: Multi-scalar drivers of land use succession and industrial restructuring in Beijing. Habitat International. Vol 46 (2015) p. 147-155.

[38] Kong J. Study on the Development of Beijing 798 Art District. New Horizons. Vol 1 (2009), p. 27-30.

[39] Waible, M. and Zielke, P. The Beijing 798 Art Zone: A Maturing Creative Cluster? Pacific News. Vol 38 (2012), p. 15-17.

[40] Information on: www.guangxinhongye.com.

[41] Wang, J. and Li, S. The rhetoric and reality of culture-led urban regeneration-a comparison of Beijing and Shanghai, China. The 4th International Conference of the International Forum on Urbanism (IFoU), TU Delft/Amsterdam, The Netherlands. (2010), p. 875-888. 